\title{
Transboundary Survival Systems: A Profile of Vulnerability
}

\begin{abstract}
The transboundary region is culturally diverse, with indigenous languages of Cushitic, Eastern Nilotic, and Omotic and Afroasiatic origin. Several ethnic groups - the Nyangatom, Turkana and Toposa - are members of the Karamojong Cluster of cultures and speak mutually intelligible languages. The Dasanech, on the other hand, are Cushitic in linguistic affiliation. At the core of the region's indigenous economies are longstanding survival systems that are highly adapted to shifting environmental and social conditions, with ethnic groups linked through complex exchange networks. In recent decades, increasing dispossession and marginalization imposed by powerful external political and economic powers since colonial times have recently forced much of the region's populationparticularly the Dasanech and northern Turkana - to settle at the Omo River or Lake Turkana as a last option means of survival. Despite centuries of resilience from even the most difficult times, these groups have now been pushed into extreme dependency on these two major water bodies and they have greatly increased vulnerability, even to stresses once familiar to them. They are now vulnerable in the extreme to massive scale destruction of their survival systems, with region-wide hunger and new mortality caused by the Gibe III dam and dam enabled irrigated agriculture along the Omo.
\end{abstract}

\section{Indigenous Livelihoods and Survival Strategy Systems}

\section{$\triangleright$ The survival strategy systems of transboundary ethnic groups have emerged from centuries of indigenous knowledge and highly adaptive survival strategy systems.}

The region's ethnic groups most heavily dependent on the Omo River or Lake Turkana are the Mursi, Bodi, Kwegu, Suri, Kara, Nyangatom, and Dasanech, in the lower Omo River basin, and the Turkana, El Molo, Rendille, Samburu, Gabbra and Dasanech along the shores of Lake Turkana (Fig. 1.3). ${ }^{1}$ Numerous neighboring groups also rely on the

\footnotetext{
${ }^{1}$ Some of the most detailed ethnographic information in the region is that for the indigenous Mursi ethnic group - residing well upstream from lowermost Omo basin and Lake Turkana region that forms the core of this book. The majority of literature for the Mursi region has emerged from research by the anthropologist, Turton $(1977,1991,1995,2013)$ and his associates, who have written numerous pieces concerning the changes in that region-most recently the major scale land grab underway along the Omo River, for Gibe III enabled commercial scale irrigated agriculture plantations. This expanding crisis, particularly as it is affecting for the Mursi and Bodi peoples (Fig. 1.3), is relatively well reported and can be accessed both at the Oxford based website, www.mursi.org, and at a number of non-governmental and other websites web sites, including Survival International, International Rivers and the Oakland Institute. Other key literature for the Omo River region, near the related Mursi group, is that for the Suri agropastoralists (Fig. 1.3) - with particularly detailed accounts and interpretations of the region produced by Abbink (1997, 2000, 2003, 2009). For the lowermost Omo River basin where the Kara, Dasanech and Nyangatom reside, the literature is less extensive - in no small part owing to the physical and political difficulties accessing the region. Critical historical accounts of the Ethiopian monarchy's expansion into the southwestern region are presented in Donham and James' edited volume, The Southern Marches of Imperial Ethiopia: Essays in History and Social
} 
river or lake - either for seasonal resource use or through exchange networks. These include the Me'en, Hamar, Dizzi, Chai, Toposa, Arbore and Pokot.

Ethnic groups in the transboundary region have historically been pastoral or agropastoral in emphasis, at least until recently, when very large numbers of them have had to resort to either strong reliance on agriculture, fishing, or both. Like pastoral peoples throughout semi-arid Africa, their survival systems comprise strategies for both risk minimization and recovery from livelihood setbacks. A striking exception to this is the El Molo ethnic group, a predominantly fishing people, residing at the southern end of Lake Turkana (Fig. 1.3).

Adaptability is key to the survival systems of indigenous groups throughout the region. This is especially true in the context of the transboundary area's wide range of environments (see Chap. 1 and below) and the periodic major stresses created by prolonged droughts, livestock and human disease epidemics, severe crop loss from pests, as well as shifting regional exchange relations and interethnic hostilities. Pressure on each group's capacity for adaptation is heightened by multiple decades of problematic government policies and especially by changes brought about by the GOE, the GOK and international finance institutions in anticipation of the Gibe III dam, along with its linked agricultural and energy transmission enterprises.

Livelihood systems of transboundary pastoral groups incorporate strategies for both risk minimization and recovery from economic losses include these general characteristics(see Figs. 4.1 and 4.2). These are outlined for the Dasanech, for example, in Carr $(1977,2012)$ and in much of the pastoral literature referred to above. Key among them are:

- Maximum accumulation of capital. Livestock are historically dominant as 'capital'- for meeting both immediate subsistence and long-term security needs.

- High mobility of livestock herds and village settlement. Complex and flexible seasonal movements between upland plains environments and riverine or lake zones provide ability to respond to changing environmental and social conditions.

- Diversification of livestock types. Cattle, small stock (goats/sheep), camels, donkeys.

- Economic diversification to alternative production activities, including:

- Flood recession agriculture (the only agriculture possible in the lowermost Omo basin) on low flats along the Omo River and in modern delta lands low enough to receive annual flood waters. ${ }^{2}$

- Fishing along the Omo River, in the delta region and along the northern shoreline of Lake Turkana, using primarily rafts and other minimal equipment.

Strong and pervasive social reciprocity relationships whereby material, labor and other forms of social exchange provide for precautionary as well as recovery measures. These relationships are generally rooted in age set based authority systems as well as clan/lineage and affinal ('in law') relationships.

(Footnote 1 continued)

Anthropology (1986). The Nyangatom agropastoralists have been studied in-depth by Tornay (1979, 1981), Tornay et al. (1997), Mark and Tornay (1992), Savary (2003) and Schroder (2003), with recent cultural investigation by Bassi (2011). Dasanech socioeconomy and human ecology has been the subject of early work by this writer (e.g., Carr 1977), while Almagor $(1978,1992)$ has produced major valuable ethnographic analysis. A critical cultural history of the Ethiopia-Sudan lands is provided by Donham and James (1986). Sobania (2011) has recently written about 'Dassanech' history, and Bassi (2011) has extended cultural history understanding by research with the Dasanech and Nyangatom). The Hamar people residing in the higher lands east of the Dasanech and the Nyangatom and closely interacting with others in the region, are not considered in this volume. Important accounts of the Hamar, with implications for the region, however, include those by Lydall and Strecker (1979) and Strecker (1988). While literature concerning the Turkana is extensive, most of it pertains to the southern and central Turkana, rather than the northern extent of Turkana territory, where the population is most vulnerable to the effects of the Omo River basin development. The works by Gulliver (1950, 1955) Gwynne (1969, 1977), Lamphear (1992), McCabe (2004), Skoggard and Adem (2010), Smucker (2006) and Fielding (2001) and Hogg (1982) are particularly useful for the purposes of understanding the Turkana in the transboundary region. The history and present crisis in the Ilemi Triangle - a contested area by all three nation states and an area with frequent and marked interethnic shifts in livelihood and territorial patterns, as well as the predictable center for a major upsurge in armed conflict among groups - is beyond the scope of this book and is the subject of a future cooperative effort.

${ }^{2}$ In large areas, particularly around Lake Turkana, high salinity conditions exist. 

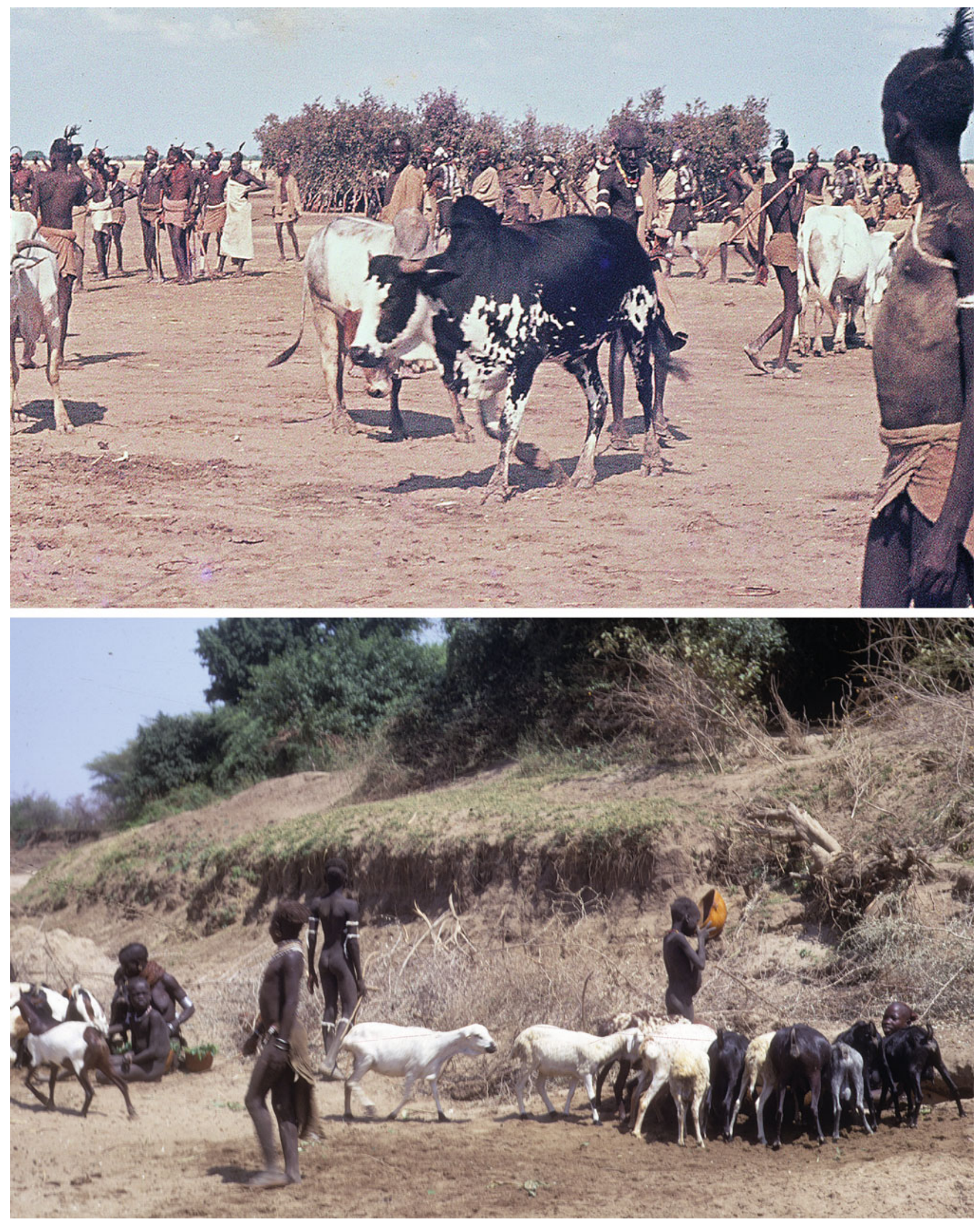

Fig. 4.1 Pastoral life along the Omo River west bank and Kibish River. Top Major Dasanech ritual (Dimi) on Omo River's west bank, with oxen/bull slaughter. Bottom Nyangatom male and female herders with small stock at deep $(7 \mathrm{~m})$ watering hole in bed of the seasonal Kibish River (see Fig. 1.3) during the long drought season 

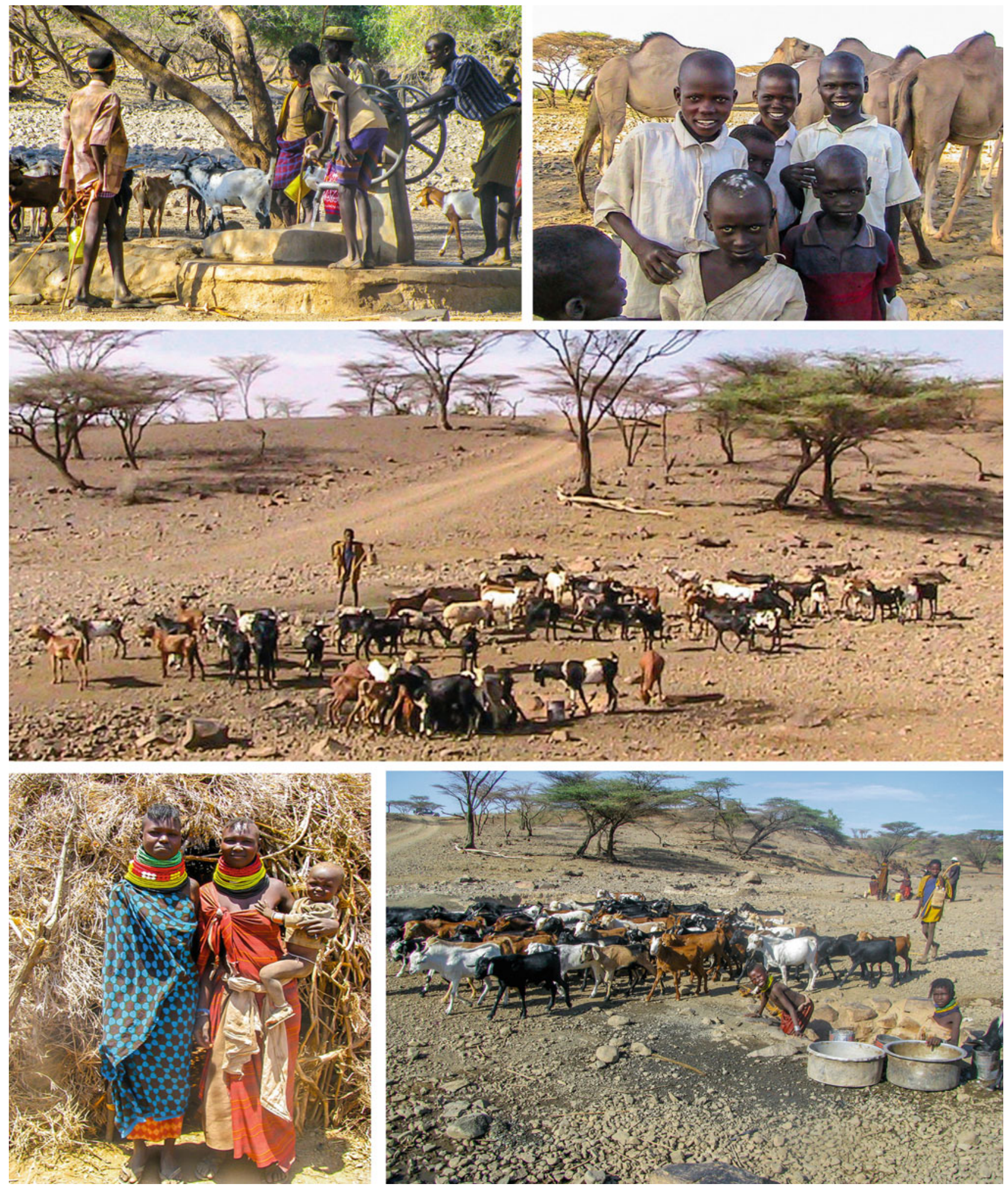

Fig. 4.2 Northern Turkana pastoralists in upland plains. Top left Turkana pastoralists with goats at working well (Oxfam funded). Top right Young Turkana camel herders. Center Small stock at hand-dug well in dry plains-near Ilemi Triangle. Lower left Northern Turkana pastoralist women and child. Bottom right Small stock at hand-dug well in Turkana (with hundreds of other livestock awaiting watering) 
From this complex set of pastoral survival strategies, the most common means of pastoral household or village level recovery from livestock loss due to drought, disease, conflict or other hazards, for example, are:

- Temporary movement of herds into peripheral lands with available pasturage and water.

- Short-term barter of small stock (goats/sheep) with communities of the same or neighboring ethnic groups, in order to meet immediate food needs. Exchange or sale of animals, farm and fishing products to Somali, Ethiopian and Kenyan traders and merchants.

- Raiding of neighboring ethnic group herding camps and villages for livestock seizure.

- Use of social exchange networks (for loans, gifts and labor cooperation) in order to meet immediate household needs and rebuild livelihood systems.

- Temporary strong reliance on subsidiary production activities.

- Diversification to new forms of production, including recession agriculture, fishing, household commodity production and most recently wage labor (mostly in Kenya).

Implementation of these strategies requires access to sufficient territory and resources - conditions that have drastically deteriorated for the Dasanech, Nyangatom and northern Turkana in the past half-century (Figs. 4.1 and 4.2).

Livelihood activities once secondary or only occasionally engaged in have recently become dominant in much of the lowermost Omo basin and northernmost Turkana region. Among the Dasanech, for example, some communities have long been agropastoral, practicing substantial flood recession agriculture in low lying, seasonally flooded areas along the Omo River or in the Omo delta. There is insufficient rainfall in the lowermost Omo basin for rainfed agriculture, so that flood recession agriculture is all that is possible in the Omo region. The Kenyan government and a few aid agencies have funded small rainfall dependent agricultural projects in the dry plans of the northern Turkana segment (including near the lake), but the vast majority of these have failed.

A small segment of Dasanech have long fished and hunted crocodile, as well (Fig. 4.3). Most Dasanech, however, sustained traditional pastoral life - until recently, that is, when major pressures on livestock herding necessitated vast numbers of households shifting to substantial, even major emphasis flood recession agriculture in the riverine zone. By the same token, agropastoralists, and even some pastoralists, have taken up fishing in the lowermost river channels and northern waters of Lake Turkana. Thousands of Dasanech fishers are now locked into intense competition with Turkana over remaining fish stocks in the lake. This conflict is undoubtedly intensified by the Ethiopian government's encouragement and subsidization of commercial fishing operations in Kenyan lake waters - operations that have far greater fishing capacity due to their large and motorized boats.

In northern Turkana, a parallel set of pressures on pastoral life has also intensified in recent decades. As in Dasanech territory, inadequate rainfall in central and northern Turkana precludes rainfed agriculture and the shorelines of Lake Turkana's saline waters are also unsuitable for planting. As declining grazing conditions for livestock in the upland plains of Turkana have become dire in recent years, major numbers of northern Turkana households — often entire village- have migrated toward Lake Turkana.

As in the transboundary region more generally, massive numbers of Turkana livestock died during the extended drought between 2007 and 2010, for example, resulting in a major spike in herd losses - a process initiated years earlier. Increasing numbers of Turkana stock owners - even entire villages - began 'migrating' from the plains toward the lake's northwestern shores (Fig. 4.4). Countless thousands of animals died during these treks, due to lack of water and graze. Tens of thousands of these once pastoral households have taken up fishing, whether or not they have retained some livestock (Fig. 4.5). Hundreds of thousands of Turkana are now dependent on fishing or fishing related livelihood. They subsist only with access to sufficient Lake Turkana waters and living resources - especially fish. From this general migration pattern (Fig. 4.5), new fishing and fishing/pastoral villages have established along the northwestern shores of Lake Turkana, from the Ethiopia-Kenya border to Ferguson's Gulf, and southward. 

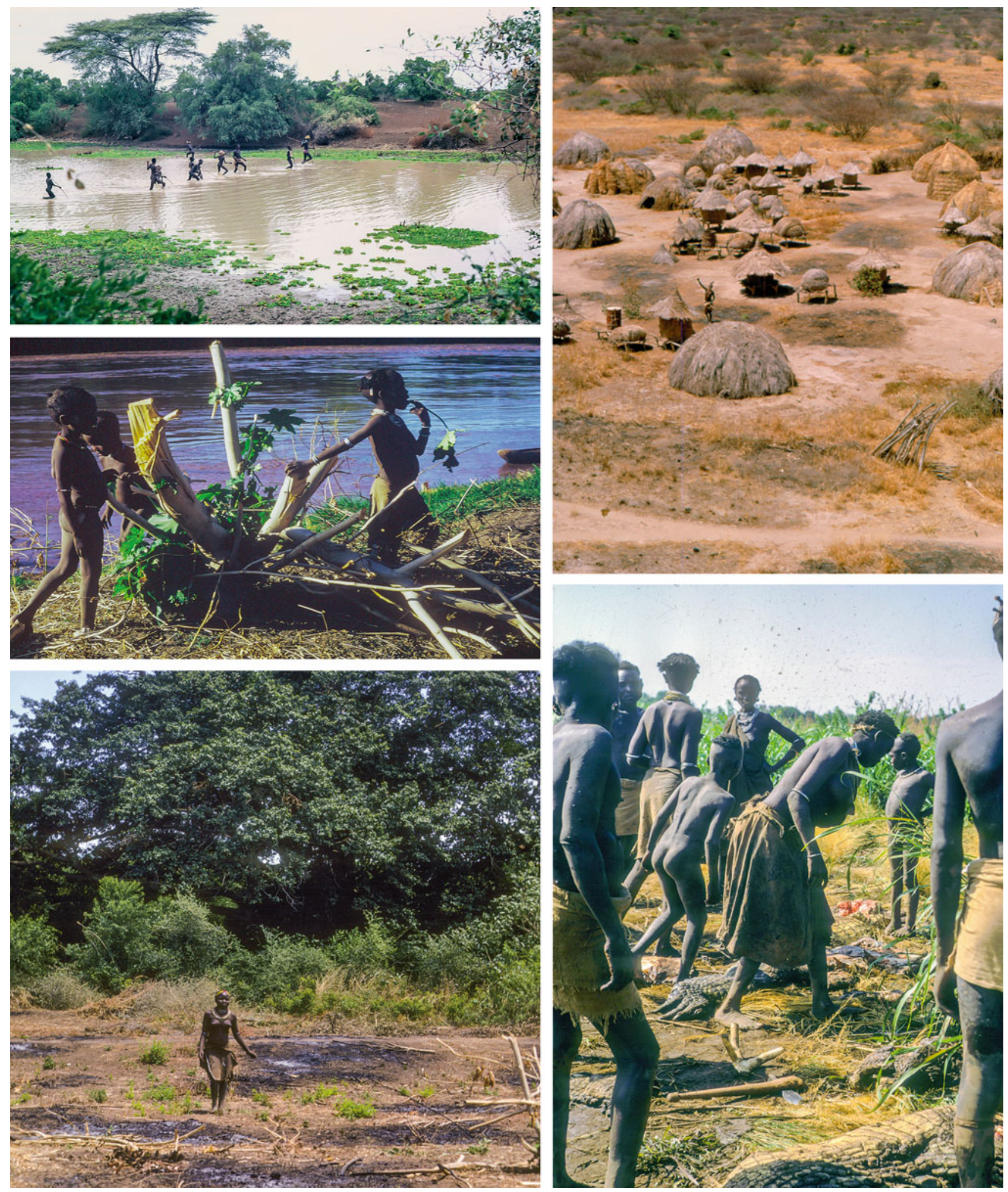

Fig. 4.3 Riverside settlement and secondary production along the lowermost Omo River. Top left Dasanech boys fishing in gathering stream (Kolon). Top right Nyangatom agricultural village, with granaries, along Omo River. Center left Children at riverside agricultural plot. Bottom left Dasanech woman after burning small recession agriculture plot (before flood). Bottom right Dasanech villagers cutting up crocodile after successful hunt 

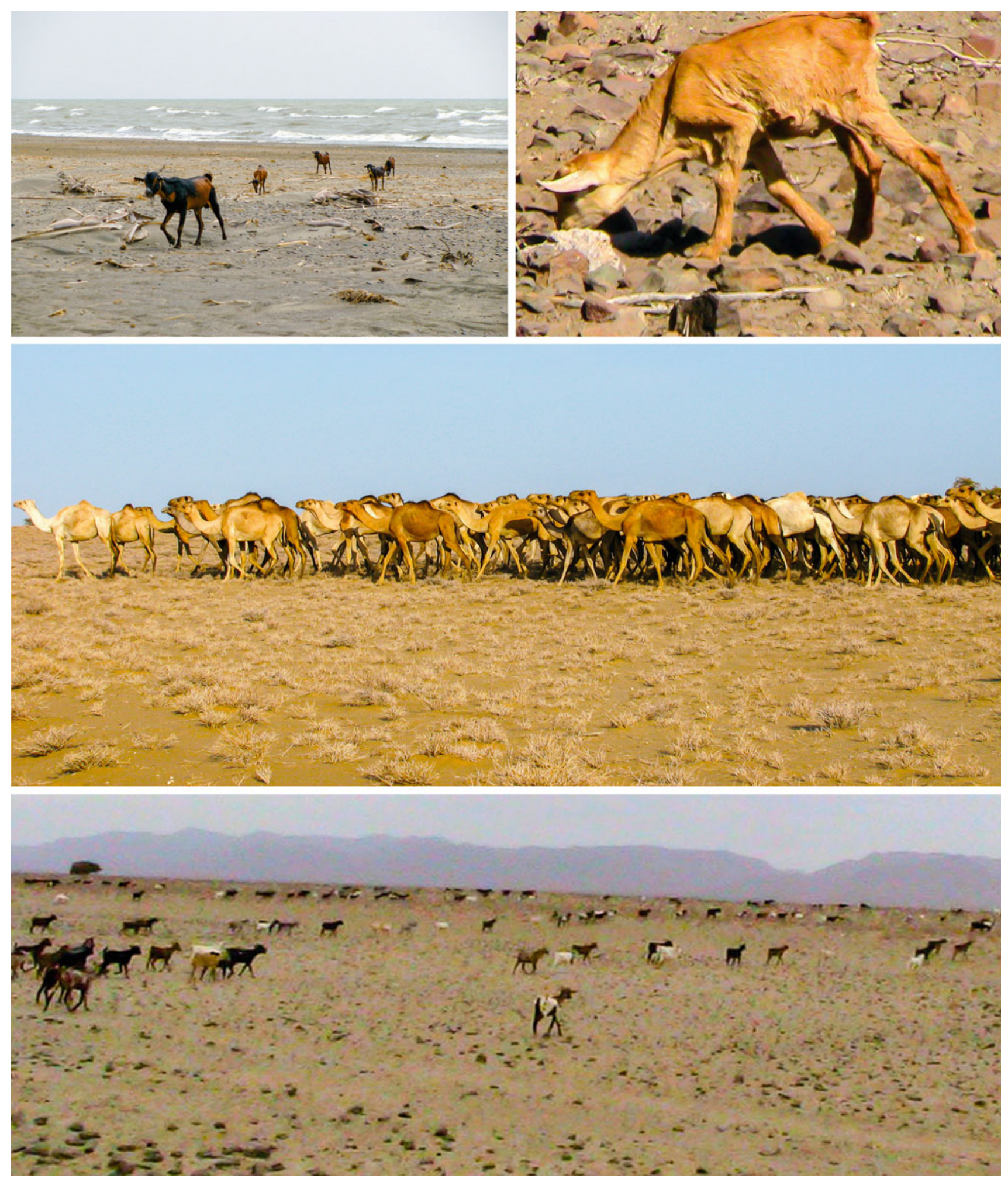

Fig. 4.4 Northern pastoral Turkana dependency on Lake Turkana for watering and grazing. Top left Goats at watering. Top right Young goat in last stage of starvation/dehydration. Center Large camel herd on watering trek to the lake. Bottom Hundreds of small stock rushing in the last kilometer of their trek to the lake for watering 

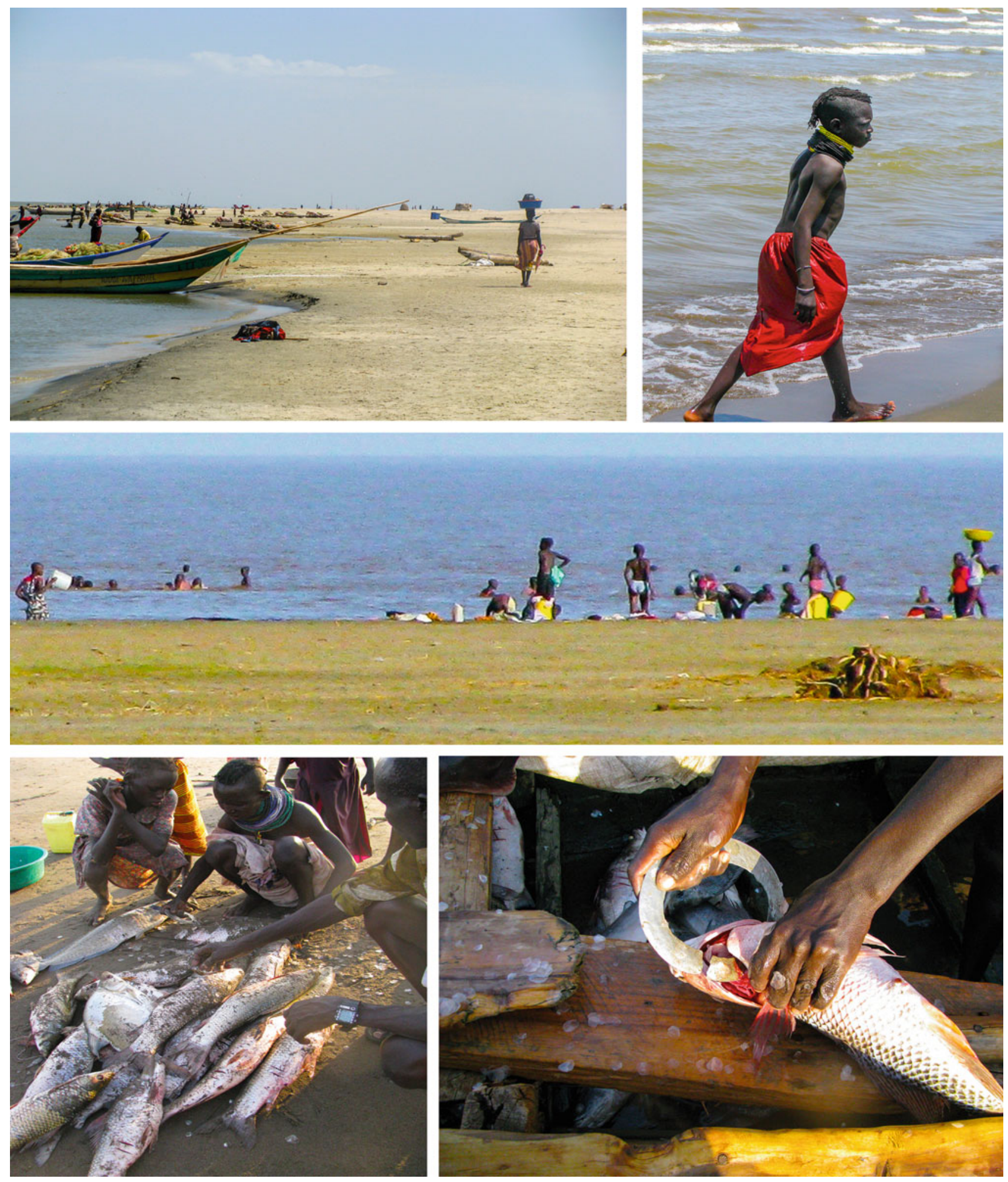

Fig. 4.5 Northern Turkana fishing villagers at Lake Turkana. Top left Non-motorized sailboats and villagers along the northwest shoreline. Top right Turkana girl at the lake. Center Bathing and water-getting north of Ferguson's Gulf. Bottom left and right Cleaning fish catch on the beach before transport to the village for drying 


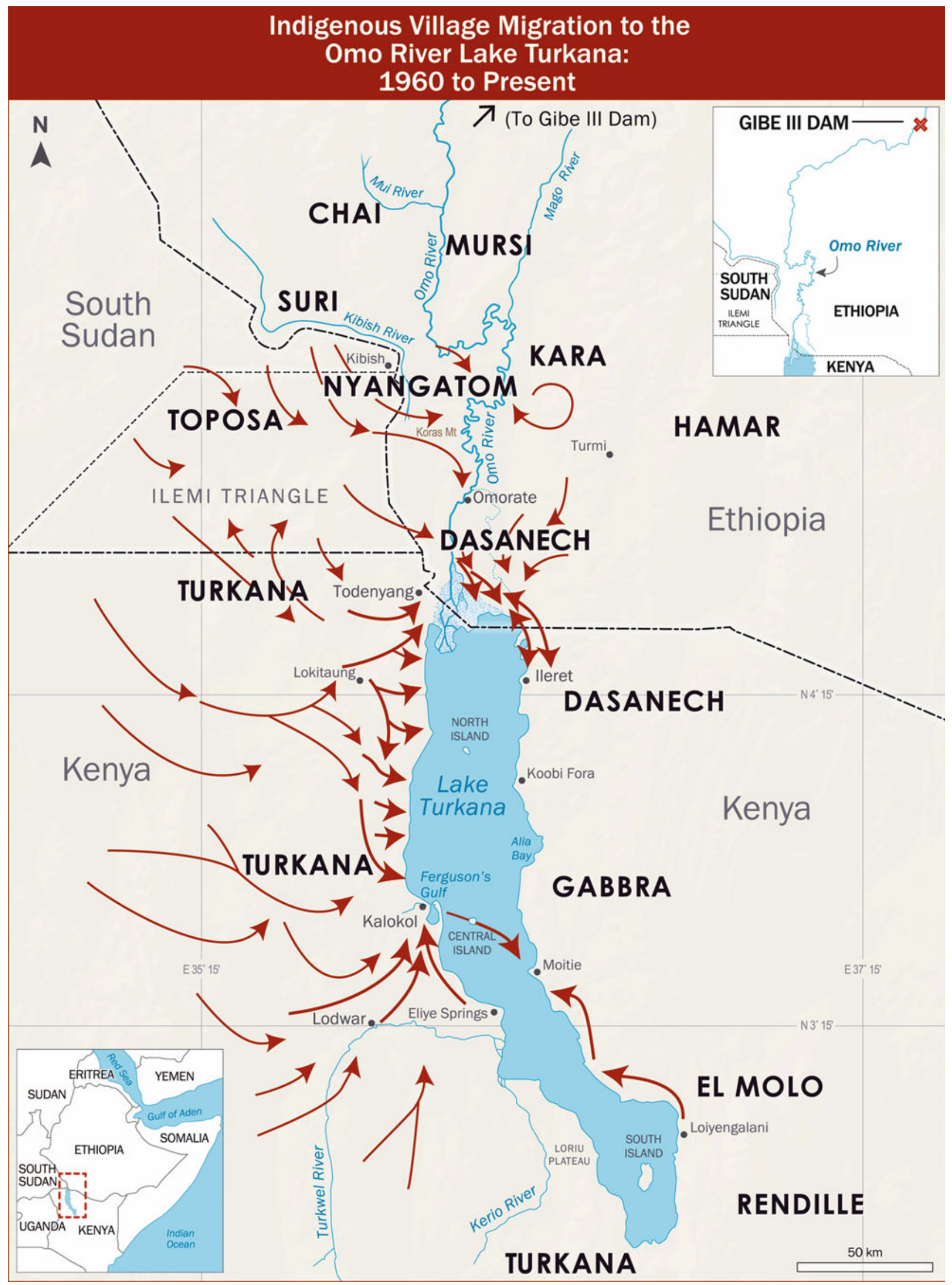

Fig. 4.6 Indigenous village relocation (migration) to the Omo River and Lake Turkana: 1960 to present. Major livelihood dependence on lake and river is at the core of the region-wide exchange network (see Fig. 1.6) 
The map of interethnic exchange relations included in Chap. 1 (Fig. 1.6) suggests the critical nature of this system for the survival of each group. This system of exchange relations is necessary for pastoralists, for example, both for herd-building and minimizing risks in herd management as well as for recovery from major livestock losses. For agropastoralists and pastoral/fishers too, exchange networks are critical for minimizing risk and recovery from such stressors as failure of Omo floodwaters to replenish agricultural plots and last resort grazing, decreased fish catch and failed local markets.

Despite a radical increase in agropastoralism over pastoralism among Dasanech households, and in fishing over pastoralism among many northern Turkana - changes following decades of disenfranchisement of both groups-cooperation among communities with divergent subsistence components remains. In peaceful periods between the Dasanech in the lowermost Omo basin and the Turkana around northern Lake Turkana, product (and sometimes labor) exchange is commonplace and involves pastoral, agropastoral and fishing communities.

The major food related exchange relations between just two sets of the region's groups are summarized in Tables 4.1 and 4.2. The full set of such relations is exponentially more complex, particularly when the full set of material and social transactions is considered. These include marriage-based exchange, labor cooperation, gift giving and loans, and political relations. These exchange relations are often key to economic diversification and the forgoing of new settlement and seasonal movement patterns among transboundary ethnic groups.

The tables suggest the core food-based exchange among three of the region's groups: the Nyangatom, the Turkana and the Dasanech - the key exchange relations among them being:

$$
\text { Small stock } \Leftrightarrow \text { Grain }+ \text { Small stock } \Leftrightarrow \text { Cattle }
$$

As diversification from pastoral to agropastoral and fishing livelihoods has become a primary means of survival for very large numbers of the region's indigenous people in recent years, new forms are preeminent in some areas, especially:

$$
\text { Fish } \Leftrightarrow \text { Small stack }+ \text { Fish } \Leftrightarrow \text { Grain }
$$

\section{Pastoral Dispossession and Rising Dependence on the Omo River and Lake Turkana}

In order to carry out their highly adaptive survival strategies, including their complex system of exchange, the region's traditionally pastoral ethnic groups have depended on access to sufficient territory, including adequate pasture areas and watering points for livestock, lands for recession agriculture and most recently-fishing locales. These conditions have been drastically curtailed in recent decades, forcing the pastoralists to depend on Omo River and Lake Turkana resource for their survival.

A wide range of colonial and post-colonial policies in eastern Africa have produced major dispossession and marginalization among transboundary indigenous groups. British colonial administrations of Kenya, Uganda, Sudan and Egypt, along with Ethiopia's monarchs-Menelik IIU and Haile Selassie-took actions that fundamentally altered the region. All of these governments engaged in border definitions, for example, that profoundly affected the region's indigenous peoples, while essentially regarding them as 'externalities.'. Major decisions were shaped without regard to the size, resource need - even the identity — of the indigenous groups concerned. This longstanding reality was described by colonial officers interviewed by this writer and in numerous written accounts in Kenyan and Sudanese archives.

Considerable documentation of these policies has emerged as part of the expanding literature for the region-most of it addressing one or another ethnic group or type of policy. Chapters 7 and 9 briefly summarize some key points from this literature, combined with information and perspective recorded from Dasanech and northern Turkana elders during investigations by SONT. 
Table 4.1 Diversified food production among transboundary ethnic groups

\section{Lower Omo Basin \& Ilemi Triangle}

\begin{tabular}{|l|l|}
\hline Kara & $\begin{array}{l}\text { Flood recession agriculture**/Agropastoral** } \\
\text { Fyangatom } \\
\begin{array}{l}\text { Dasanech (upland, } \\
\text { riverine) }\end{array}\end{array}$ \\
$\begin{array}{l}\text { Pastoral*, Fishing** } \\
\text { Foposa }\end{array}$ & $\begin{array}{l}\text { Flood recession agriculture**/Agropastoral**, } \\
\text { Fishing**, Pastoral* }\end{array}$ \\
Hamar & $\begin{array}{l}\text { Agropastoral, Pastoral } \\
\text { Pastoral, Agropastoral } \\
\text { Pastoral, Agropastoral, Bee-Keeping }\end{array}$ \\
& $\begin{array}{l}* * \text { Year-round dependence on Omo River or Lake Turkana } \\
\text { * Seasonal dependence on Omo River or Lake Turkana }\end{array}$ \\
&
\end{tabular}

\section{Lake Turkana Region}

\begin{tabular}{|l|l|}
\hline $\begin{array}{l}\text { Dasanech (Omo delta and } \\
\text { east shoreline of lake) }\end{array}$ & $\begin{array}{l}\text { Flood recession agriculture**, Agropastoral**, } \\
\text { Turkana }\end{array}$ \\
Gabbra & $\begin{array}{l}\text { Pastoral*, Fishing**, Pastoral-Fishing** } \\
\text { Pastoral * }\end{array}$ \\
El Molo & $\begin{array}{l}\text { Fishing**, Fishing-Pastoral** } \\
\text { Rendille }\end{array}$ \\
Samburu & $\begin{array}{l}\text { Pastoral * } \\
\text { Pastoral * }\end{array}$ \\
& $\begin{array}{l}* * \text { Year-round dependence on Omo River or L. Turkana } \\
\text { * Seasonal dependence on Omo River or Lake Turkana }\end{array}$ \\
\hline
\end{tabular}

\section{Major Subsidiary Livelihood Activities (groups vary)}
Wild Food Gathering/Harvesting**
Utensil manufacture
Beekeeping/Honey Gathering** .
Fishing gear/net manufacture
Boatbuilding**
Firewood/charcoal preparation*
Chicken-raising
Fish marketing**
Utensil and tool making 
Table 4.2 Major food related exchange: Turkana-Nyangatom and Dasanech-Turkana ethnic groups

\begin{tabular}{|c|c|c|c|}
\hline \multicolumn{2}{|c|}{ Turkana- Nyangatom } & \multicolumn{2}{c|}{ Dasanech-Turkana } \\
\hline $\begin{array}{c}\text { From } \\
\text { Turkana: }\end{array}$ & $\begin{array}{c}\text { From } \\
\text { Nyangatom } \\
\text { (Omo) }\end{array}$ & $\begin{array}{c}\text { From } \\
\text { Dasanech }\end{array}$ & $\begin{array}{c}\text { From } \\
\text { Turkana }\end{array}$ \\
\hline $\begin{array}{c}\text { Animal } \\
\text { skins/hides }\end{array}$ & $\begin{array}{c}\text { Sorghum, } \\
\text { Peas, } \\
\text { Beans, Squash, } \\
\text { gourds }\end{array}$ & $\begin{array}{c}\text { Sorghum, } \\
\text { Peas, } \\
\text { Beans, } \\
\text { Sive animals } \\
\text { (mostly small } \\
\text { stock) }\end{array}$ & $\begin{array}{c}\text { Animal } \\
\text { gourds } \\
\text { skins/hides }\end{array}$ \\
$\begin{array}{c}\text { Cooking pans } \\
\text { (Fish) }\end{array}$ & & $\begin{array}{c}\text { Live cattle and } \\
\text { small stock }\end{array}$ \\
& & Live small & Fishing \\
& & stock and cattle & netsear \\
& & & \\
\hline
\end{tabular}

In the tri-nation border area, several types of colonial and post colonial policies have impacted all three major groups- the Dasanech, Nyangatom and northern Turkana, with differences in timing, intensity and outcomes of specific actions. These policies centered around:

- Redrawing of national boundaries.

- Policing agreements, often with financial subsidies to the administrating government.

- Territorial relocation or expropriation of indigenous groups and population segments within them-including for the purposes of political control, privatization of lands, settlement programs.

- Disarmament of villagers - including through forceful/brutal campaigns.

- Establishment of 'closed district' or 'no-go' zones.

- Livestock seizure-for example, as reprisals for aggressive actions, 'punishment' for incursion into declared no-go zones.

- Provision of firearms to indigenous fighting groups - for 'protection' of a particular group, and/or to establish a 'proxy' force for governmental agendas.

- Taxation-hut, population or livestock based.

- Increased militarization, with expanding security apparatus.

- Imposition of government appointed authority systems, replacing indigenous ones.

Some of these policies have been applied in one area, yet they have impacted the region more generally. For example, territorial dispossession of a particular pastoral or agropastoral group has occurred both directly, with forcible removal by a government, or indirectly, through expropriation of a neighboring group - one de facto forced to push into the transboundary region, intensifying resource competition. Such occurrences have affected the Pokot, Jie Toposa, Hamar, Gabbra, Rendille and Samburu neighboring groups. To some extent, the complex exchange network among the region's ethnic groups (Fig. 1.6) reflects such repercussions.

$>$ The Ilemi Triangle (Figs. 1.1 and 4.7) forms a critical part of the transboundary region's history of indigenous group marginalization and dispossession. A disputed area between South Sudan and Kenya and one bordering Ethiopia, the Ilemi Triangle is named after a major chief (Ilemi Akwon) from the Anuak group that now resides in the Gambella region of Ethiopia/South Sudan borderlands. The Ilemi covers a vast area: 10,320 or $14,000 \mathrm{~km}^{2}$, depending on the political boundary adopted.

The Ilemi-viewed by colonial and post colonial administrations alike as 'wasteland', 'unoccupied' (by permanent settlements) and with little if any value - nevertheless demanded certain political decisions since the early twentieth century, though these have nearly all been informal ones. The national boundaries in the tri-nation border region have remained in 'quiet' dispute - even following the Italian invasion and occupation of the region, the end of World War II, a number of 


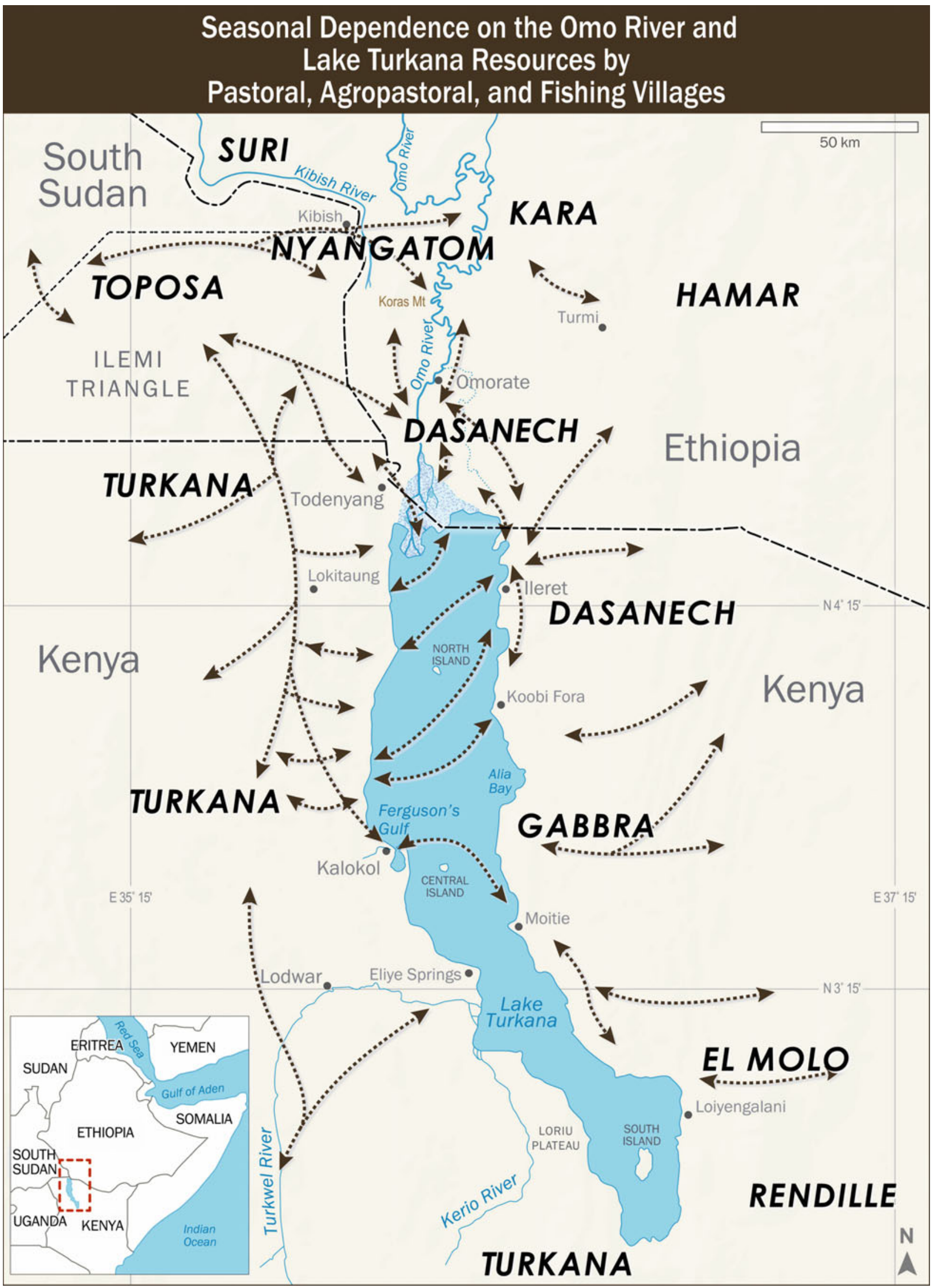

Fig. 4.7 Seasonal dependence on Omo River and Lake Turkana resources by pastoral, agropastoral, and fishing indigenous communities. East/west bank (Omo River) Dasanech and cross-lake movements by Turkana fishers have sharply increased 
'modernization' efforts, and most recently, public acknowledgment by the respective governments of major oil and gas reserves there. ${ }^{3}$ As this book goes to print, there are onconflicting reports regarding possible legal settlement between the governments of South Sudan and Kenya in this matter.

The significance of the Ilemi Triangle, and jurisdiction over it, for understanding the present status of the Dasanech, the Nyangatom and the northern Turkana and their vulnerability to decimation by the Omo River basin development (and now, extractive industry), is at least five-fold.

- In the first place, the grasslands of the region, particularly in its central and northwestern portions with rolling plains and relatively wetter foothills, are superior to nearly all those of the transboundary region. Especially during dry seasons, countless thousands of livestock from the region's different ethnic groups have flocked to the region-well prior to the military and political incursions by the region's colonial (and imperial/monarchy) powers and the shifting political arrangements among them.

- Secondly, the multiple ethnic groups in the region, while periodically engaging in conflict (with traditional weapons-not firearms, prior to the 20th century), also sustained complex cooperative and sharing relations with regard to watering locales, high value grazing areas and other issues, according to Dasanech and Turkana elders.

- Thirdly, governments have commonly exploited the indigenous groups' pressing need for access to Ilemi pastures by supplying them with arms and using them as 'proxy' forces in asserting their national territorial interests - the rhetoric of "protecting indigenous grazing rights" aside. This practice is heightened by the extensive arms trafficking within the region. The proxy character of indigenous fighters has been evident since the 1939 Italian occupation of the Ilemi and the 1941 routing of the Italians by Kenyan British forces. It continues to the present day dynamics in the region, with traditional weaponry virtually replaced by new brutality and scale of killing among ethnic groups.

- Fourthly, as numerous portions of this book suggest, the collapse of indigenous economies in the lower Omo basin and around Lake Turkana, due to Gibe III dam and linked agricultural enterprise development would catapult Dasanech, Nyangatom and Turkana into explosive new armed conflict—expanding from existing 'hot spots' (see Fig. 5.4), as all groups desperately search for rapidly disappearing resources within the Ilemi region.

- Finally, extensive oil and gas reserves in the Ilemi and the broader transboundary region, coupled with oil industry operations underway there, have intensified the boundary claims of Kenya and Sudan, in particluar. However these national claims unfold, the indigenous groups face yet worsened dispossession and marginalization, precisely when their circumstances are already at a crisis level.

Considerable scholarly accounts concerning the Ilemi Triangle/national boundary dispute have been produced in recent years, including that by Collins (2004, 2005), Mburu (2001, 2003), Lamphear (1992) and Blake (1997), as well as a large number of government and international agency reports. With some variation in specifics, these accounts are in general agreement about the historical trajectory of boundary arrangements.

A series of negotiated demarcations are chronicled from 1902/1907 through 1972, when informal agreement for Kenyan administration of the Ilemi was reaffirmed between Sudan and Kenya, along with Ethiopia's position of having no claim to the region. These boundary shifts are mapped in Mburu's (2003) account, for example. As the literature noted above details, the basic agreements among the region's governments began with Britain's 1902 survey of the border between Kenya and Ethiopia with a border referred to as the 'Maud line'-recognized in 1907, and allocating all of the Ilemi region to Sudan. This was immediately followed by the Ethiopian emperor Menelik II's claim of northern Kenyan lands to the southern end of Lake Turkana and eastward to the Indian Ocean. The British colonials responded with the Uganda-Sudan Boundary Commission agreement in 1914 that secured Sudan's access to Lake Turkana via the dry saltpan locale, Sanderson's Gulf (see Chap. 6). Other than that, the 1914 boundary within the Ilemi remained ambiguous. After some trading of administrative responsibility between the British of Sudan and Kenya, a 'Red line' agreement was established in 1931-five years before the Italian occupation of the region. The Red line was drawn under the rubric of 'protecting the grazing lands' of the northern Turkana. This line was once again reaffirmed between Kenya and Sudan in 1938. The effects of these administrative and policing shifts, combined with the ebb and flow of arms availability to the Dasanech, the Nyangatom and the Turkana, resulted in major conflicts among the groups.

\footnotetext{
${ }^{3}$ As Appendix A points out, the reserves were actually known to exist for decades - at least, by the oil corporations who had been exploring there, top officials of the governments and the World Bank.
} 
Recapture of the Ilemi in 1941 by British forces, as they pushed into Ethiopia from Sudan — part of the campaign that reinstated Haile Selassie to the throne — once again led to a shift in boundaries. This time, the Kenyan administration drew a 'Blue line' - further north from the 'Red line' - thus extending its jurisdiction. In 1950, the Sudan government established a line relatively far to the west as its 'patrol line' - a move that Kenya later argued relinquished the Ilemi land. In reality, none of these boundary lines were legally binding in international terms. The Kenyan/Ethiopian border definition was reaffirmed by both parties in 1972, as was Ethiopia's confirmation that it had no claim on the Ilemi.

Meanwhile, by the 1960s, the Kenyan government designated the Ilemi a closed 'buffer zone' by agreement with the Addis government - excluding even their previously favored Turkana, as well as the Nyangatom and the Dasanech. All three groups were excluded and only small groups with their herds were able to 'poach' (as the Kenya police viewed it) the relatively rich grassland resources that they desperately needed, having experienced dispossession from their respective countries' policies and a number of years of extreme drought. Excursions into the Ilemi were extremely dangerous for the herders—risking seizure of their livestock by the Kenya police, often with brutal measures. ${ }^{4}$

This policy proved destructive for the Dasanech, the Nyangatom, and ultimately, the Turkana.

- The Dasanech were forced eastward into Ethiopia - effectively confining them to the area between the Kibish River and the Omo River, since their hostile relations with the Hamar prevented them from crossing the river.

- The Nyangatom were essentially split into two segments: those with villages along the Kibish River and the Omo River and those remaining near the Toposa (Fig. 1.3), slightly northwest of the heavily policed lands of exclusion. Travel and exchange between them however, continued.

- The Turkana were pushed southward into the harsher upland plains of northern Kenya.

\section{All faced severe hardships from these changes - hardships that became crises during severe droughts and high disease incidence, even epidemics, as this writer experienced in the course of several research periods during the early 1970s.}

By the late 1970s, the Kenyan government began encouraging herding and settlement in the Ilemi of Kenya's Turkana. Most observers interpreted this as a 'proxy' move to reassert Kenya's interests. The Dasanech remained excluded from lands they clearly regarded as traditionally theirs, so they perceived little recourse but to attack their neighbors. The Nyangatom, while officially barred from the Ilemi by the Kenyans, already had many households living nearby their close relatives, the Toposa (Fig. 1.3). Although under increased stress, the Nyangatom sustained much of their transhumant movement among their settlements along the Omo and Kibish Rivers, and in the Ilemi.

Ethiopian border presence remained minimal until the 1980s when the government began increasing its presence along the lower Omo River. Kenya continued to administer the Ilemi, with police posts at Kibish and several other locales. Kenyan police frequently seized large numbers of livestock belonging to the pastoralists—sometimes even shooting the herders.

The Ilemi continued to be administrated by Kenya. Until the region's oil and gas potential became an active issue in government circles (oil companies had been exploring the region for years), the contested nature of the Ilemi remained largely dormant. Oil corporations sharply increased their interest and involvement in the region during the 1980s, and this process has since accelerated. Land grabs and government issuing of leases and concessions are well underway (see Appendix A).

$>$ Largely due to these major territorial losses - compounded by prolonged droughts, shifting ethnic alliances and conflicts, and regional government policies - both people and livestock were overcrowded in numerous areas throughout the region. Overgrazing by the increasingly crowded livestock initiated a radical decline in herd numbers-one so severe that the long-standing economic recovery strategies were no longer effective. These conditions led to ecological

\footnotetext{
${ }^{4}$ This writer did extensive ecological transecting and study in the eastern Ilemi during the early 1970s (see Chap. 7 and Carr 1977) and personally encountered a number of small groups of herders and livestock seeking safe places for their animals to graze. Relations with the Kenya police ranged from poor to atrocious, as evidenced by one Kenya police officer who stated that "shooting Dasanech is more fun than shooting gazelle." Kenyan police assigned to the region from the highlands commonly had antipathy for the marginalized pastoralists, and certainly they detested the extreme heat and dryness of the region.
} 
deterioration throughout much of the dryland plains of the transboundary region, except for the restricted Ilemi lands. None of the three pastoral groups really recovered from their many years of dispossession in their respective countries and within the Ilemi. Livestock mortality continued at a high level, as village survey in both northern Turkana and Dasanech areas indicate (Chaps. 7 and 9). Herd sizes plummeted for the vast majority of households and villages.

The pastoralists' longstanding strategies for recovery outlined above have proven insufficient for a massive proportion of the northern Turkana and Dasanech in particular, so tens of thousands of them turned to the only remaining resource systems available to them —at the Omo River and along the shores of Lake Turkana. By the 1980s, the Omo delta had expanded considerably considerably, offering new resource availability for that helped local communities cope with the effects of earlier territorial losses (see Fig. 1.2).

The general patterns of migration, or relocation to the Omo River and to Lake Turkana are indicated in Fig. 4.6. Households continue to herd whatever livestock they have left—often by combining herds and cooperating in labor for stock camps, including in distant areas where still possible. Along the Omo River, most of the locales for flood recession agriculture are already spoken for as this large displaced population searches for possible planting land and for livestock grazing and watering locales. Well-established social and material exchange patterns between the Dasanech and Turkana, like those of nearby ethnic groups (Fig. 1.6), have altered with these settlement shifts and accompanying changes in mobility and economy (see Chap. 7 for changes in the traditionally complex strategies for household/village level herd management since the 1970s).

The Omo River and Lake Turkana are central to the present day seasonal shifts in survival strategies of the Dasanech, Nyangatom and northern Turkana peoples. Their general seasonal patterns are represented in Fig. 4.7patterns for herding, planting and fishing that are conditioned by major shifts in the character of water and biological resources of the river and lake, as well as precipitation levels and other conditions in the broader region.

The relatively recent major spike in livelihood dependency on the Omo River and Lake Turkana resources by transboundary residents leaves them vulnerable in the extreme to radical reduction of river and lake waters. The precipitous drop in river flow volume and shoreline retreat of the lake caused by the Gibe III dam and dam enabled irrigated agriculture spell unprecedented disaster for the region's indigenous population.

\section{Environments in the Transboundary Region: From Pristine to Degraded}

$>$ With the exception of the Omo riverine forest and some volcanic outcrop locales, most of the transboundary region's pristine habitats have undergone severe environmental deterioration in recent decades (see Carr 1977, 1998; Ebei and Akuja 2008; Gil-Romera et al. 2011). As noted above, this ecological degradation results primarily from overgrazing due to overcrowding of livestock and people following the major the territorial losses noted above (also see Chaps. 7 and 9). These losses have been compounded by prolonged drought periods and other externally generated political and economic influences, including GOE expropriation of villagers' resources along the Omo River.

Only isolated pockets of natural habitat remain, including large sections of the Omo riverine forest (prior to current government cutting and clearing), certain volcanic highland locales and upland plains areas where watering places for livestock are absent or where interethnic hostilities preclude herding. Much of the unique biodiversity and ecological integrity of the region has declined to the point where environmental restoration is required. The destruction of water resource access and resources in the downstream Omo zone and around Lake Turkana, caused by Gibe III dam and irrigated agricultural development, would force villagers throughout the region to move into the remaining natural areas in the effort to avert decimation of their livelihood systems.

$>$ The transboundary zone's ecological communities are diverse compared with most other semi-arid regions of Sub-Saharan Africa. This is largely the result of the region's complex geological, depositional and water/soil conditions (Fig. 1.9). Habitats range among those associated with the Omo River, including annually flooded riverside flats, relict river meander channels ("ox-bows"), non-flooded natural levees with variable soil moisture relations, tributaries and numerous incomplete or relict channels, and the modern delta (now about $500 \mathrm{~km}^{2}$ in area following its recent expansion (Fig. 1.2); the 
Kibish River and gathering streams; relict beach ridges. basin pans and relict floodplains; Lake Turkana with its complex lacustrine and littoral habitats, the Turkwel and Kerio Rivers and numerous small ephemeral channels; scattered volcanic highland areas, rock outcrops and tuffaceous exposures, and salt springs.

Biodiversity in the transboundary region strongly corresponds with these environmental differences. It is further enhanced by the region's position as a zone of convergence among contrasting ecological zones. ${ }^{5}$ These characteristics are strongly reflected by the results of plant collections made by this writer in the lower Omo region, including in riverine, dryland plains and volcanic areas (Carr 1977, 1998) — species identified are listed in Appendix B. ${ }^{6}$ Additional plant collecting has been carried out in the lower Omo and northern Turkana regions by F.H. Brown (summarized in a forthcoming article) with staff from the Kenya Herbarium in Nairobi. Raymonde Bonnefille has made extensive pollen collections in the northern Turkana/lower Omo Basin region.

Large wildlife populations have been recorded in recent decades throughout the lower Omo basin, Ilemi Triangle, and northern Turkana regions. Eland, oryx, topi, Burchell's zebra, hartebeest, lion, leopard, cheetah, elephant, bat-eared foxes, gazelle, and gerenuk have long inhabited the region's grasslands and other dryland environments. Omo riverine (or 'gallery') forest and woodland areas support a rich wildlife population including hippo, elephant, crocodile, at least three species of primates, kudu, bushbuck, waterbuck leopard, and a wide variety of bird species including fish eagle, goliath heron, and dwarf bittern. These wildlife populations have plummeted in recent years, both from habitat destruction resulting from the changes outlined above and from the pervasive use of weapons throughout the region.

\section{The Lowermost Omo River Basin and Environs}

$\gg$ From its source waters in the highlands of Ethiopia, the Omo River descends gradually through a series of gorges in the highlands of the northern portion of the lower basin where it is bordered by steep slopes and a mixture of riparian forest, woodland and drier plant communities. Continuing its southward flow, the river opens into broad semi-arid lowlands where it forms a strongly meandering pattern and continues to its terminus at the northern end of Lake Turkana (Fig. 1.3).

The low-lying waterside flats along the river—primarily silt berms and sand/silt bars annually flooded by the Omo- provide the conditions for vitally important flood recession agriculture by Kara, Nyangatom and Dasanech villagers. The Kara also plant in ox-bow channels when Omo floods are sufficient. Nyangatom settled along the Kibish River (Fig. 1.3) plant there when water in that seasonal watercourse is sufficient to flood their plots, and the Dasanech plant throughout much of the active delta as well as on flats along the lowermost Omo. These patterns are outlined in Chaps. 7 and 8.

Although grasslands predominate throughout this southernmost section of the lower basin (the upland areas are described in Chap. 7), the region actually supports a mosaic-like pattern of vegetation types, due to its complex soil depositional patterns and anomalous geomorphic features. Sand and silt-sand relict beaches and clay basins are punctuated by volcanic highlands, pronounced cracking patterns, salt springs and other features. The oxbow channels with seasonal floodwater inundation by the Omo River add to the complexity of plant communities. ${ }^{7}$ Nearly all of the rangelands between the Kibish River and the Omo River (Fig. 4.7) are highly degraded from overcrowding of livestock.

The forest along the lower Omo is the last pristine riverine forest in Sub-Saharan African drylands. Forest and woodland dominate the natural levees and the immediate levee backslope along the Omo River except on strong outside river bends,

\footnotetext{
${ }^{5}$ With some notable and important exceptions, the flora and vegetation types in southwestern Ethiopia closely resemble those of the Ilemi region and eastern Africa - a relatively recently determined relationship confirming earlier predictions by the well-known British botanist in East Africa, Gillett (1955).

${ }^{6}$ This writer has completed plant taxonomic studies, along with collection and ecological characterization of more than two thousand plant specimens. A full set of the collection (prepared in duplicate) is deposited at KEW Gardens Herbarium in London and another at the National Museum of Kenya, in Nairobi.

${ }^{7}$ Arguably one of the least-described regions of eastern Africa, the impressionistic and often subjective accounts by early colonial explorers offer important clues to early subsistence patterns among the area's indigenous groups. These include descriptions by Vannutelli and Citerni (1887), D'Ossat and Millosevich (1900) and Von Hohnel (1938). Butzer (1971a, b) describes a series of expeditions that passed through the Omo delta during the early twentieth century. With the 1967 beginning of the international Omo Expedition directed by Clark Howell, Richard Leakey and Yves Coppens, concrete description of the area was undertaken in a number of scientific dimensions over a period of years. This effort included extensive geomorphology, hydrology and soil studies by Butzer, Brown, Cerling and associates as well as direct paleontological investigations. It also supported detailed riverine and upland vegetation and soil studies, as well as cultural ecological and land use investigations by this writer.
} 
with drier (xerophytic) vegetation, from Omorate northward along the river (Figs. 1.9 and 4.7). The forest is sustained only with sufficient saturation, or infiltration of the Omo's natural levee soils from the Omo River's annual flood (generally between August and December). Overbank flooding does not occur in the forest zone of the Omo-a reality misrepresented entirely by the GOE. This writer has carried out detailed studies of the riverine forest and its development, some key features of which are summarized in Chap. 8 .

The forest and woodland provide resources are of fundamental importance to the survival systems of the region's indigenous communities. In addition to the recession agriculture along waterside flats and slopes bordering the forest, transition zone vegetation from forest and woodland (see Chap. 8) provides last resort graze and browse for Nyangatom and Dasanech livestock and resources for wild plant gathering. Most species in the forest and woodland are limited to that environment and are key to the biodiversity (both floral and faunal) of the lower Omo basin.

The Omo River does not flood the vast 'floodplains,' or mudflats, lateral to the river throughout much of the lowermost basin, since these are relict (or ancient) floodplains. Moreover, rainfall in the lowermost basin is insufficient for rainfed agriculture to be practiced these relict features. The Ethiopian government's misrepresentation of these realities in its downstream impact assessment (GOE 2009b) is a key reason for the report's invalidity, since the GOE asserts not only that these lands are flooded (and thus support planting), but also that rainfed agriculture in these lateral plains could compensate for the loss of flood recession planting lands along the river, due to flow reduction by the Gibe III dam. In fact, neither survival option exists for the Dasanech and Nyangatom.

Rainfall in the region is inadequate for rainfed agriculture to be practiced in the relict floodplains, despite repetitive GOE assertions that this practice is widespread. The significance of this misrepresentation rests with indigenous agropastoralists and others not having an option of rainfed agriculture as an alternative to flood recession planting.

Since precipitation is low and erratic, ground water recharge is a critical factor in the maintenance of both riverine zone and floodplain ecosystems. The vegetation in these areas-mostly scrub-like grasses and clustered herbaceous ground vegetation - forms a highly irregular pattern, corresponding to micro-level soil and drainage variations as well as irregular distribution of rainfall and pooling during the rainy season. Vegetation cover is of major significance in preventing soil evaporation and large-scale erosion. Soil evaporation and large-scale sheet erosion.

$>$ All major dimensions of Dasanech livelihood presently depend on the sustainment of the Omo riverine/delta environment. The roughly 500 square kilometer modern Omo delta (Fig. 1.2), detailed in Chap. 7, is flooded annually over large areas by the Omo River. Its vegetation ranges from woodland (limited in extent) to a variety of grasslands and wetlands, forming highly complex patterns in response to even small shifts in sediment deposits, nutrients and water conditions determined by the river.

The major livelihood components of the Dasanech and Nyangatom residing along the river would be eliminated since most of the Omo River's modern delta where last option grazing, flood recession agriculture and settlements occur would be desiccated by the effects of the Gibe III dam and its linked irrigated agricultural development.

\section{Lake Turkana and Environs}

$>$ Lake Turkana is the second largest lake in Kenya and the world's largest desert lake. More than $90 \%$ of its waters derive from Omo River inflow. The lake is one of the most saline lakes in the Great Rift Valley and the second most saline in Africa. The lake is only borderline potable for humans, livestock, and many wildlife species.

- Both the Turkwel River and the Kerio River flow into Lake Turkana (Fig. 1.1). Inflow from the Turkwel has been radically reduced from the construction of a hydroelectric dam at Turkwel Gorge, about $150 \mathrm{~km}$ from the lake. Lake Turkana has no outlet since the separation from the Nile basin (Butzer 1971a).Because it is a closed-basin lake, fluctuations in the level of Lake Turkana are determined by inflow from rivers and by evaporation, which is generally accepted to be about $2330 \mathrm{~mm} / \mathrm{year}$. 
- Lake Turkana is the most saline lake in East Africa containing a normal fish fauna. Salinity is already at a level critical for various fauna and at the extinction level for mollusks (Yuretich and Cerling 1983). Citing L.C. Beadle's early work, the authors also note that at a higher salinity, dwarfism of fish occurs. Building on studies by Hopson (1975), Wood and Talling (1988) recorded a dissolved salt content of 2440 ppm—nearly double the safe level in Kenya's "Guide Value." Although lake waters are technically within the range of potability for livestock, herd animals frequently refuse the saline waters, even after lengthy watering treks (Fig. 4.4). Turkana villagers report numerous health problems associated with high salinity.

- The Omo River's annual flood produces an extensive plume of nutrients and sediment-laden freshwater and is key to the replenishment of Lake Turkana's entire ecological system, including the sustainability of its fisheries. This nutrient and freshwater inflow can reach the central portion of the lake and stimulates fish spawning as well as fish feeding cycles in the lake. Reproductive areas of fish are mostly concentrated along the northern shoreline, in Ferguson's Gulf, Alia Bay and other shoreline areas (see Fig. 1.3 and Chap. 5).

The major reduction of Omo River overall flow volume and inflow to Lake Turkana during the planned closure of the Gibe III dam while efforts to fill its reservoir proceed would disrupt the downstream hydrology and ecological systems of the Omo River and Lake Turkana - transforming the habitats essential to the life cycles of the more than 50 species of fish identified so far in the lake and delta waters.

- Seasonality of the lake and access to fishing localities shifting with seasons is a key component of indigenous communities settled along Lake Turkana. The annual flood pulse from the Omo River, combined with the prevailing winds and currents in the lake, combine to establish several major seasonal differences. The lake is exposed to strong winds during certain months, with the prevailing winds from the southeast being a critical factor in the mixing of lake waters and nutrients. Local fishers define seasons in terms of the combination of changes in winds, lake level, nutrients and fishing conditions.

$>$ Although low in fish species diversity, Lake Turkana has about 50 species, 13 of which are important in the economy of resident fishing communities. These species range from pelagic to demersal and their distributions largely conform to the habitat factors noted above. Tilapia spp. and Nile perch, for example, are central to Turkana fishing economy and their survival depends on the health of the lake's ecosystem. These fish would be severely impacted, if not almost eliminated, without sustainment of their major reproductive and/or feeding habitats in shoreline or northern lake/delta areas. Fish species and Lake Turkana habitats critical to the survival of the indigenous people are identified in the section below concerning Turkana livelihood.

Wildlife at Lake Turkana has been abundant, with parks internationally recognized for their richness and uniqueness. The lake is home to Nile crocodile, hippos, turtles, and bird species numbering in the hundreds-including flamingos, cormorants, ibises, skimmers, and sandpipers, as well as highly threatened populations of turtle, Nile crocodile, and hippo populations - but remains essentially unprotected. These include populations in the UNESCO World Heritage site, Lake Turkana National Park (on the western shore), Sibiloi National Park (on the eastern shore), and island parks (both Central Island National Park and South Island Park. Most wildlife areas have suffered major degradation and habitats now face threat of destruction for a variety of reasons, especially from political and economical forces causing overcrowding of people and livestock, with resultant habitat destruction, the abundance of firearms throughout the region due to arms trafficking between Kenya and South Sudan, and commercial encroachment.

$>$ Several hundred thousand pastoral and fishing Turkana live in villages along or nearby Lake Turkana's western shoreline and are almost entirely dependent on the lake for household water, livestock watering and nearby grazing, fishing - or all of these. As described in Chap. 8, this population is particularly concentrated around Ferguson's Gulf and Kalokol (Fig. 1.3) and northward into the Kenya-Ethiopia border. The overwhelming majority of the fishing Turkana have migrated from pastoral lands far removed from the lake, following major herd losses. Many arrive with no livestock at all. By all accounts, this migration has dramatically increased in recent years for a variety of reasons discussed below. A nearly rainless period extended for almost three years in much of the lower Omo basin and northern lake region in recent years, for example, resulting in major livestock mortality and sparking new migration. 
The majority of Turkana villages along the lakeshore are oriented primarily to fishing, although some retain small numbers of livestock (small stock). Most households engage in some type(s) of secondary production, and many receive occasional international food aid. Turkana pastoralists bring tens of thousands of livestock-goats, sheep, cattle and camels from the upland plains to the lake for watering and grazing during drought months (Fig. 4.4). Recent ecological degradation of littoral and shoreline environments is a critical problem for both Turkana residents and visiting herders, as noted in Chap. 9. Fishing communities depend on the maintenance of delicate environmental and biological balances in shoreline habitats, with even small shifts affecting fish catch levels. Trading relations between fishing communities and slightly more removed pastoral/fishing communities are essential to both.

Central and northern upland environments around the central and northern portions of Lake Turkana are similar to those of the lower Omo basin and those of the eastern Ilemi in terms of rainfall. The region is semi-arid with a mean annual precipitation of less than $250 \mathrm{~mm}$. Rainfall is unpredictable in the extreme, both in total amount and in distributionconditions to which Turkana pastoralists have long been adapted (Fig. 4.2). The seasonal movement patterns indicated in Fig. 4.7 point to the high mobility of the transboundary indigenous population, including the pastoral Turkana.

The radically deteriorated conditions for Turkana livelihood (and that of the Dasanech at the lake's northeastern shoreline) would advance to disaster level with radical withdrawal of lake waters in the extremely shallow fringes of central and northern Lake Turkana - an inevitable result even during the planned Gibe III dam filling period (whether 2 years or multiple years), let alone from continued operation of the dam and from the abstraction of river waters for the large-scale irrigated agricultural works underway.

\section{Cross-Border Conflict and Diminishing Resources: The Ilemi Triangle Ingredient}

$>$ Localized conflicts in the transboundary region have been escalating in recent years. This is primarily due to worsening resource deterioration and poverty conditions throughout, continued dispossession fueled by government policies, prolonged droughts and disease outbreaks. Climate change, while likely to be a major factor of increased vulnerability of the local population to the impacts of the looming dam and irrigated agricultural development, has not been responsibly studied in the region. Finally, rampant arms trafficking continually expands throughout the region and contributes to the upward spiral of violence.

- Most destructive among government policies are the Ethiopian government's large-scale, forcible evictions of indigenous communities along the lowermost Omo River (as well as upstream in Mursi/Kwegu/Bodi territory) in order to make way for large-scale, irrigated commercial agricultural schemes. Major irrigation infrastructure construction brings further expropriation and destruction of resources necessary for local residents' survival, as well and creates major blockages to mobility of herd animals.

- The Kenya government's present acceptance of the Gibe III dam and irrigated agriculture - at least by the time of this writing, and the Kenyan government's active partnership in the transmission of electricity from the Gibe III to Kenya and beyond are additional major destructive policies.

Rising tensions over dwindling grazing resources and watering points has intensified long-established interethnic tensions and conflicts, major locales for which are shown in a map below. These stresses have also weakened the extensive regional system of food related exchange - a system important to the survival of all groups (Fig. 1.6). Similar impacts on social exchange have been noted for comparable pastoral regions by Abbink (2000, 2009), Teqegn (2003), and Hendrickson et al. (1998a, b).

The numerous 'hot spot' conflict localities where conflict is already intensifying and can be expected to spike even more sharply as the Gibe III dam and agricultural enterprises are allowed to operate, are indicated in a map in Chap. 5. The overwhelming response by governments and the private groups active in the region, notably including Tullow Oil, is militarization. 


\section{Literature Cited}

Abbink, J. 1997. The shrinking cultural and political space of East African pastoral societies. Nordic Journal of African studies 6(1): 1-17.

Abbink, J. 2000. Restoring the balance: Violence and culture among the Suri of Southern Ethiopia. In Meanings of violence: A cross cultural perspective, Eds. G. Aijmer and J. Abbink, pp. 77-100.

Abbink, J. 2003. The yellow guns - Generations and politics in Nyangatom (Ethiopia). Africa 73(3): 473-474.

Abbink, J. 2009. Conflict and social change on the south-west Ethiopian frontier: An analysis of Suri society. Journal of Eastern African Studies 3 (1): $22-41$.

Almagor, U. 1978. Pastoral partners: Affinity and bond partnership among the Dassanetch of South West Ethiopia, 258 pp. England: Manchester University Press.

Almagor, U. 1992. Institutionalizing a fringe periphery: Dassanetch-Amhara relations. In The Southern Marches of imperial Ethiopia, Eds. D.L. Donham, W. James, and Jean-Pierre de Monza, pp. 96-115.

Bassi, M. 2011. Primary identities in the lower Omo Valley: Migration, cataclysm, conflict and amalgamation, 1750-1910. Journal of Eastern African Studies 5(1): 129-157.

Blake, G.H. (ed). 1997. Imperial Boundary Making: The Diary of Captain Kelly and the Sudan-Uganda Boundary Commission of 1913. Oxford University Press.

Butzer, K.W. 1971a. Recent history of an Ethiopian Delta. Chicago: University of Chicago, Department of Geography Papers, Research Paper No. 136.

Butzer, K.W. 1971b. The Lower Omo Basin: Geology. Fauna and Hominids of Plio-Pleistocene Formations, Naturwissenschaften 58(1): 7.

Carr, C.J. 1977. Pastoralism in crisis: The Dassanetch of Southwest Ethiopia. Chicago: University of Chicago, Department of Geography Papers, 319 pp.

Carr, C.J. 1998. Patterns of vegetation along the Omo River in southwest Ethiopia. Plant Ecology 135(2): 135-163.

Carr, C.J. 2012. Humanitarian catastrophe and regional armed conflict brewing in the border region of Ethiopia, Kenya and South Sudan: The Proposed Gibe III dam in Ethiopia, Africa Resources Working Group, 250 pp. https://www.academia.edu/8385749/Carr_ARWG_Gibe_III_ Dam_Report.

Collins, R. 2004. The Ilemi Triangle. Unpublished manuscript.

Collins, R. 2005. The Ilemi Triangle. Annales d'Ethiopie 20:5-12.

Donham, D., and W. James (eds.). 1986. Southern marches of imperial Ethiopia: Essays in history and social anthropology. Athens: Ohio University Press.

D’Ossat, G., and F. Millosevich. 1900. Seconda Spedizione Bottego. Roma: Studio geologico sul materiale raccolto de M. Sacchi, 212 pp.

Ebei, P., Oba, G. and T. Akuja 2008, Long-term impacts of droughts on pastoral production and trends in poverty in north-western Kenya. In Droughts: Causes, effects and predictions, Ed. J.M. Sanchez, pp. 103-138. New York: Nova Science Publishers.

Fielding, D. 2001. Turkana Herders of the dry Savanna (Book Review). Quarterly Review of Biology, vol. 76, no. 1.

Gillett, J.B. 1955. The relation between the highland floras of Ethiopia and British East Africa. Webbia 9: 459-466.

Gulliver, P. 1950. A preliminary survey of the Turkana compiled for the government of Kenya. University of Capetown.

Gulliver, P. 1955. The family herds: A study of two pastoral tribes in East Africa: The Jie and Turkana. London: Routledge and Kegan Paul.

Gwynne, M.D. 1969. A bibliography of Turkana. Nairobi: Royal Geographical Society South Turkana Expedition.

Gwynne, M.D. 1977. Land use by the southern Turkana, 16-18. Paper prepared for seminar on Pastoral Societies of Kenya: Institute of African Studies, University of Nairobi.

Gil-Romera, G., D. Turton and M. Sevilla-Callejo. 2011. Landscape change in the lower Omo valley, southwestern Ethiopia: Burning patterns and woody encroachment in the savanna. Journal of East African Studies, pp. 108-128.

Hendrickson, D., J. Armon, and R. Mearns. 1998a. Conflict and vulnerability to famine: Livestock raiding in Turkana, Kenya, Drylands Programme. International Institute for Environment and Development no. 80.

Hendrickson, D., J. Armon, and R. Mearns. 1998b. The changing nature of conflict and famine vulnerability: The case of livestock raiding in Turkana District, Kenya. Disasters 22(3): 185-199.

Hogg, R. 1982. Destitution and development: The Turkana of North West Kenya human nutrition. Disasters 6(3): 164-168.

Hopson, A.J. 1975. Preliminary notes on the birds of the Lake Turkana area, pp. 17.

Lamphear, J. 1992. The scattering time: Turkana responses to colonial rule, 308 pp. Oxford: Oxford University Press.

Lydall, J. and I. Strecker. 1979. The Hamar of Southern Ethiopia. 3 Vols. Arbeiten aus dem Institute fur Völkerkunde der Universität zu Göttingen —Bendiz. Hohenschäftlarn: Klaus Renner Verlag.

Mark, P., and S. Tornay. 1992. Les Fusils jaunes: Générations et politique en pays Nyangatom (Ethiopie). African Studies Review 46(1): 196-198.

Mburu, N. 2001. Military decline of the Turkana of Kenya 1900-2000. Nordic Journal of African Studies 10(2): 148-162.

Mburu, N. 2003. Delimitation of the elastic Ilemi Triangle: Pastoral conflicts and official indifference in the Horn of Africa. African Studies Quarterly (Sprg).

McCabe, J.T. 2004. Cattle bring us to our enemies: Turkana ecology, politics, and raiding in a disequilibrium system. Michigan: University of Michigan Press.

Savary, C. 2003. Generations and politics among the Nyangatom of Ethiopia. Anthropos 98(1): 278-280.

Schroder, P. 2003. Generations and politics among the Nyangatom of Ethiopia. Anthropos 98(1): 267.

Skoggard, I., and T.A. Adem. 2010. From raiders to rustlers: The filial disaffection of a Turkana age-set. Ethnology 49(4): $249-262$.

Smucker, T.A. 2006. Cattle bring us to our enemies: Turkana ecology politics. Professional Geographer 58(2): 231-233.

Sobania, N. 2011. The formation of ethnic identity in South Omo: the Dassenech. Journal of Eastern African Studies 5(1): 195-210.

Strecker, I. A. 1988. The Social Practice of Symbolization: An Anthropological Analysis. Monographs on Social Anthropology, no. 60. London. Athlone Press.

Teqegn, M. 2003. The marginalization of pastoral communities in Ethiopia. Indigenous Affairs 4: 32-37.

Tornay, S. 1979. Armed conflicts in the lower Omo Valley, 1970-1976: Nyangatom Society. Senri Ethnological Studies 3: 97-117. 
Tornay, S. 1980. The hamar of Southern Ethiopia, conversations in Dambaiti by Strecker, I. Homme 20(2):99-108.

Tornay, S. 1981. The Nyangatom an outline of their ecology and social organization in peoples and cultures of the Ethio-Sudan Borderlands, pp. 137-178, Ed. M.L. Bender. East Lansing, Michigan: African Studies Center, Michigan State University.

Tornay, S., K.W. Butzer, J.A. Kirchner, Fuller, G.K., Lemma, A., Haile, T., Bulto, T., Endeshaw, T., Abebe, M., Eshete, S., Petros, G.P. and D.H. Van. 1997. The growing power of the Nyangatom. Chicago: University of Chicago.

Turton, D. 1977. Response to drought: The Mursi of Southwestern Ethiopia. Disasters 1(4): 275-287.

Turton, D. 1991. Warfare, vulnerability and survival a case from Southwestern Ethiopia. Disasters 15(3):254-264.

Turton, D. 1995. Pastoral livelihoods in danger, cattle disease, drought, and wildlife conservation in Mursiland, S.W. Ethiopia. pp. 50. Oxfam Research Paper 12, Oxfam (UK and Ireland).

Turton, D. 2013. Aiding and abetting: UK and US complicity in Ethiopia's mass displacement. London: Think Africa Press.

Vannutelli, L. and Citerni, C. 1887. Relazione preliminare sui risulati geografici della deconda spedizione Bottego. Society Geographical Italiana, Series 3, 10: 320-330.

Von Hohnel, L. 1938. The Lake Rudolf region: Its discovery and subsequent exploration, 1888-1909. Journal of Royal African Society, London 37(16-45): 206-26.

Wood, R.B. and J.F. Talling. 1988. Chemical and algal relationships in a salinity series of Ethiopian inland waters. Hydrobiologia 158: $29-67$.

Yuretich, R.F. and T.E. Cerling. 1983. Hydrogeochemistry of Lake Turkana, Kenya: Mass Balance and Mineral Reactions in an Alkaline Lake. Geochimica et Cosmochimica Acta, vol. 47 (Jun); 1099-1109.

Open Access This chapter is distributed under the terms of the Creative Commons Attribution-NonCommercial 2.5 International License (http:// creativecommons.org/licenses/by-nc/2.5/), which permits any noncommercial use, duplication, adaptation, distribution and reproduction in any medium or format, as long as you give appropriate credit to the original author(s) and the source, provide a link to the Creative Commons license and indicate if changes were made.

The images or other third party material in this chapter are included in the work's Creative Commons license, unless indicated otherwise in the credit line; if such material is not included in the work's Creative Commons license and the respective action is not permitted by statutory regulation, users will need to obtain permission from the license holder to duplicate, adapt or reproduce the material.

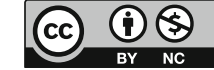

